\title{
1 Quantifying the Fate of Wastewater 2 Nitrogen Discharged to a Canadian River
} 3

21 of the discharge points.

\section{Abstract:}

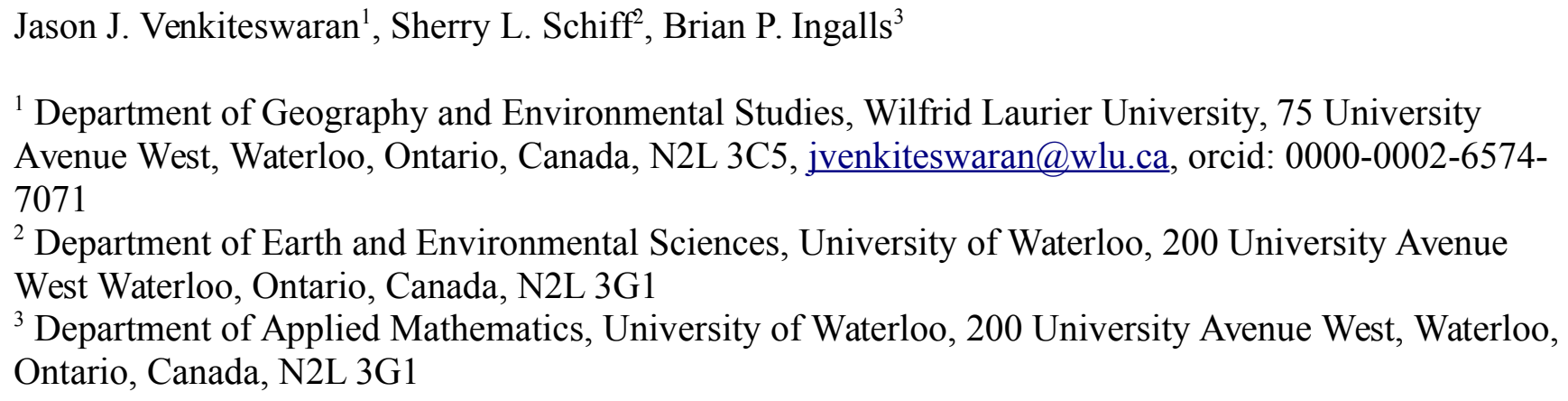

Addition of nutrients, such as nitrogen, can degrade water quality in lakes, rivers, and estuaries. To predict the fate of nutrient inputs, an understanding of the biogeochemical cycling of nutrients is needed. We develop and employ a novel, parsimonious, process-based model of nitrogen

concentrations and stable isotopes that quantifies the competing processes of volatilization, uptake, nitrification, and denitrification in nutrient-impacted rivers. Calibration of the model to nitrogen discharges from two wastewater treatment plants in the Grand River, Ontario, Canada show that ammonia volatilization was negligible relative to uptake, nitrification, and denitrification within $5 \mathrm{~km}$ 


\section{Introduction:}

Nitrogen $(\mathrm{N})$ is essential for life but can be present in the environment in excess of growth requirements due to human activities. $\mathrm{N}$ is a common point-source pollutant to aquatic systems from waste-water treatment plants (WWTPs). Nitrate $\left(\mathrm{NO}_{3}{ }^{-}\right)$and total ammonia nitrogen (TAN; where TAN includes both ammonia $\left(\mathrm{NH}_{3}\right)$ and ammonium $\left(\mathrm{NH}_{4}{ }^{+}\right)$) are the two inorganic $\mathrm{N}$ forms that determine the critical loads beyond which aquatic ecosystems experience eutrophication or acidification (Posch et al 2001, Schindler et al 2006). The fate of these inorganic $\mathrm{N}$ species is a key determinant in the health of ecosystems and the services they provide to humans. TAN can be both a fertilizer of and detriment to aquatic life. At elevated concentrations, $\mathrm{NH}_{3}$ is toxic to aquatic life.(Canadian Council of Ministers of the Environment 2010) Similarly, elevated concentrations of $\mathrm{NO}_{3}{ }^{-}$degrade water quality by harming aquatic life (Canadian Council of Ministers of the Environment 2012) and above drinking water limits can lead to adverse health effects in people (Iwanyshyn et al 2008). Consequently, understanding the environmental fate of TAN and $\mathrm{NO}_{3}{ }^{-}$discharged to surface waters is important for managing of humandisturbed aquatic ecosystems.

Many processes remove $\mathrm{N}$ from aquatic ecosystems. By understanding the relative contributions of each process and the factors that affect their rates, the environmental fate of $\mathrm{N}$ loading to aquatic ecosystems can be predicted (Iwanyshyn et al 2008). Successful nutrient mitigation strategies in larger aquatic ecosystems rely on using smaller, tractable ecosystems as realistic and replicatable systems (Schindler 1998, Sharpley et al 2009, Webster et al 2003, Dodds and Welch 2000, Withers and Lord 2002). The concept of nutrient spiralling in streams was developed to describe the cycling and transport of nutrients in small lotic ecosystem(Newbold et al 1981, 1982, 1983) and is based on downstream changes in nutrient concentrations. Isotope tracer experiments, where ${ }^{15} \mathrm{~N}$-enriched compounds are added and the tracer followed through different pools, have improved spiralling techniques.(e.g. Mulholland et al 2000, 2008, Tank et al 2000, Earl et al 2006, Hall et al 2009, Mulholland et al 2004).

In a similar fashion, low nutrient streams can be spiked with nutrients and changes in the nutrient pulse can be used to understand ecosystem metabolism of nutrients (e.g. Davis and Minshall 1999, Hall and Tank 2003). These studies are often restricted to short lengths of streams where the hydrology can be well characterized and to smaller systems in general. The understanding of nutrient spiralling in large impacted rivers is often confounded by a heterogeneous river morphology, frequent run-of-the-river 
52 dams, groundwater and multiple nutrient inputs, and consequently relies on the intensive work

53 conducted in these smaller systems supplemented by sampling campaigns of both concentration and

54 stable isotopes of $\mathrm{N}$ species. Further, observed values are a cumulative result of a plethora of

55 contemporaneous $\mathrm{N}$ cycling processes with rates that change in relative importance with distance from

56 inputs and time of day. Disentangling the relative rates of these processes in large rivers is greatly aided

57 by the additional information supplied by stable isotopes and the development of numerical

58 model(Denk et al 2017).

59 Stable isotope studies in rivers have shown that (i) $\mathrm{NH}_{4}{ }^{+}$is preferentially incorporated into the food 60 web compared to $\mathrm{NO}_{3}{ }^{-}$and (ii) some TAN is lost to volatilization to the atmosphere while some is 61 nitrified to $\mathrm{NO}_{3}^{-}$(Loomer 2008, Murray 2008, Hood et al 2014). Denitrification results in $\mathrm{N}$ attenuation 62 in rivers, but to a lesser extent in well oxygenated rivers(Rosamond et al 2011, 2012, Laursen and 63 Seitzinger 2002, 2004). The rates of these processes change from day to night in response to the release 64 of photosynthetic $\mathrm{O}_{2}$ into the water(Venkiteswaran et al 2007, 2015, Wassenaar et al 2010). $\delta^{15} \mathrm{~N}$ values 65 have been used to qualitatively identify anthropogenic $\mathrm{N}$ in coastal areas(Fourqurean et al 1997, Fry et 66 al 2000, Savage and Elmgren 2004, Derse et al 2007). Few studies have attempted to quantify the 67 importance of these competing processes and their role in attenuation of WWTP TAN and $\mathrm{NO}_{3}{ }^{-}$in lotic 68 systems though these processes set the baseline $\delta^{15} \mathrm{~N}$ (isotopic ratios are hereafter reported as $\delta$ values) 69 values used for benthic invertebrate and fish studies(e.g. Hood et al 2014, Loomer et al 2014).

70 Novel technical developments in the analysis of stable isotopes have allowed for improved 71 assessment of nitrogen cycling in rivers including the use of the differences in $\delta^{15} \mathrm{~N}^{-} \mathrm{N}_{2} \mathrm{O}$ and $\delta^{18} \mathrm{O}-\mathrm{N}_{2} \mathrm{O}$ 72 produced by nitrification versus denitrification (Thuss et al 2014). Similarly, ecosystem metabolism 73 techniques (Venkiteswaran et al 2007, Tobias et al 2007, Holtgrieve et al 2010, Parker et al 2010) have 74 recently been improved by the use of diel $\delta^{18} \mathrm{O}-\mathrm{O}_{2}$ and $\delta^{13} \mathrm{C}$-DIC modelling (Murray 2008, Fourqurean 75 et al 1997, Fry et al 2000, Savage and Elmgren 2004). The isotopic labelling of benthic biofilm by 76 differing $\mathrm{NH}_{4}{ }^{+}$and $\mathrm{NO}_{3}{ }^{-}$sources has recently been describe (Hood et al 2014, Loomer et al 2014, 77 Peipoch et al 2014). Here, we build on these studies by developing and testing a model that uses 78 changes in concentrations and natural abundance stable isotopic ratios to quantify the contributions of 79 the various nitrogen-removal pathways in nutrient-impacted rivers. We applied this model to quantify 80 the fate of $\mathrm{N}$ from the WWTP effluent discharges in a river highly impacted by both agricultural and 


\section{WWTP nutrients.}

82 The objectives of this research are to (1) quantify changes in concentrations and $\delta^{15} \mathrm{~N}$ values of TAN 83 and $\mathrm{NO}_{3}{ }^{-}$with distance downstream from WWTPs; (2) develop a parsimonious process-based model

84 for $\mathrm{N}$ cycling and the fate of WWTP $\mathrm{N}$ in rivers, and assess model performance with field 85 measurements; and (3) provide model-based estimates of the rates of nitrification, denitrification, $\mathrm{NH}_{3}$ volatilization, and N assimilation in WWTP plumes in a river impacted by both WWTP and agricultural nutrient inputs.

\section{Methods:}

Field Site:

The Grand River is the largest river discharging into the Canadian side of Lake Erie (Figure 1).

Almost 1 million people live in its watershed and more than half of those rely on the river for drinking water. There are 30 wastewater treatment plants of varying sizes in the watershed where agriculture is the dominant land use (80\%). We have previously studied the $\mathrm{N}$ and $\mathrm{O}_{2}$ cycling in the Grand River (Rosamond et al 2011, 2012, Jamieson et al 2013, Venkiteswaran et al 2014, 2015). Here, we focus on two large WWTPs in the central part of the watershed that serve a combined population of about 96230,000 .

97 Ecosystems the size of the Grand River are not amenable to experimental isotope tracer additions but nevertheless afford us the opportunity to assess many of the processes resultant from the discharge of nitrogen-rich WWTP effluent. These processes include assimilation of $\mathrm{NH}_{4}^{+}$by primary producers, nitrification of $\mathrm{NH}_{4}{ }^{+}$to $\mathrm{NO}_{3}^{-}$, loss of $\mathrm{NH}_{3}$ to the atmosphere via volatilization, denitrification of $\mathrm{NO}_{3}^{-}$, and dilution of both $\mathrm{NH}_{4}{ }^{+}$and $\mathrm{NO}_{3}{ }^{-}$. Rather than simply a point-source addition of nutrients to a pristine ecosystem, WWTP effluent in the Grand River increases nutrients in an already nutrient-rich system 103 (Venkiteswaran et al 2015).

104 The upstream Waterloo WWTP serves an urban population of approximately 120,000 and discharges 105 a mix of $\mathrm{NH}_{4}{ }^{+}$and $\mathrm{NO}_{3}{ }^{-}$via a pipe on the west side of the river. The plume hugs that bank of the river 106 for several km downstream. At baseflow, WWTP discharge accounts for 10-25\% of river flow along 107 this reach. The downstream Kitchener WWTP serves about 205,000 and discharges mostly $\mathrm{NH}_{4}{ }^{+}$via a 108 diffuser in the middle of the river. The plume hugs the east bank of the river for several km downstream 
109 before several large river bends result in lateral mixing. The river is about 50m wide through the entire 110 sampling area. Together, the WWTPs discharge about 900 tonnesN/yr (Table S1).

111 In the study reach, the Grand River flows over the stony and sandy Catfish Creek till (Karrow 1974).

112 This forms a substrate for the patchy growth dominated by the macroalga Cladophora spp. and 113 macrophytes Myriophyllum spicatum and Stuckenia pectinatus. Their biomass (about $\left.1 \mathrm{~kg} / \mathrm{m}^{2}\right)$ is 114 greater below both WWTPs than above (Hood 2012).

115 Water in the Grand River is hard with dissolved inorganic carbon (DIC) concentrations around $11650 \mathrm{mgC} / \mathrm{L}$. Municipal drinking water, from both the Grand River and groundwater, is similarly hard, 117 averaging $400 \mathrm{mg} / \mathrm{L}$ equivalents of $\mathrm{CaCO}_{3}$. The use of residential water softeners produces WWTP 118 effluent high in $\mathrm{Cl}^{-}$(Region of Waterloo 2011). River dissolved organic carbon (DOC) concentrations 119 are typically 6-8 $\mathrm{mgC} / \mathrm{L}$. The river is shallow through the sampled section, with mean depth at 120 baseflow around $0.5 \mathrm{~m}$. Typical river discharge during the sampling periods through these reaches was $1212-13 \mathrm{~m}^{3} / \mathrm{s}$ (Canadian Water Survey, https://wateroffice.ec.gc.ca/). Sampling occurred during stable 122 base-flow conditions.

123 Agricultural activity and some small WWTPs in the watershed results in high nutrient concentrations 124 in the river prior to the two main WWTPs in this study. Upstream $\mathrm{NO}_{3}{ }^{-}$concentrations are elevated (3$1254 \mathrm{mgN} / \mathrm{L})$ whereas $\mathrm{NH}_{4}{ }^{+}$concentrations are low $(<0.1 \mathrm{mgN} / \mathrm{L})$ and both total phosphorus (TP) and 126 soluble reactive phosphorus (SRP) are high $(70$ and $10 \mu \mathrm{g} / \mathrm{L})$.

127 Below each of the two WWTPs, eight sampling points were established based on availability of 128 access to the river (Figure 1). The first site was immediately downstream of the effluent discharge 129 point, one was a few hundred kilometres downstream, and the others about every $800 \mathrm{~m}$ to $1000 \mathrm{~m}$ for 130 about $5 \mathrm{~km}$ (Table S2). At each site, samples for $\mathrm{NH}_{4}{ }^{+}, \mathrm{NO}_{3}{ }^{-}, \mathrm{Cl}^{-}, \mathrm{DOC}, \delta^{15} \mathrm{~N}_{-} \mathrm{NH}_{4}{ }^{+}$, and $\delta^{15} \mathrm{~N}_{-} \mathrm{NO}_{3}{ }^{-}$were 131 collected from the centre of the plume as identified by in situ measurement of conductivity (YSI 556 132 MPS). Samples were collected in HDPE bottles and immediately chilled in a cooler for transport to the 133 laboratory, filtered to $0.45 \mu \mathrm{m}$, and kept cold $\left(4^{\circ} \mathrm{C}\right)$ until analyses. Samples for $\mathrm{NH}_{4}{ }^{+}$and $\delta^{15} \mathrm{~N}_{-} \mathrm{NH}_{4}{ }^{+}$ 134 were immediately acidified to $\mathrm{pH} 4$ with $\mathrm{HCl}$ and frozen until analyses. In situ measurements of 135 temperature and $\mathrm{pH}$ were made (YSI $556 \mathrm{MPS}$ ) with reported accuracy on $\mathrm{pH}$ and temperature of $136 \pm 0.2$ units and $\pm 0.15^{\circ} \mathrm{C}$, respectively. To account for dilution of the effluent plume by river water, $\mathrm{Cl}^{-}$ 137 at these elevated concentrations was assumed to be a conservative tracer and $\mathrm{NH}_{4}{ }^{+}$and $\mathrm{NO}_{3}{ }^{-}$ 
concentrations were adjusted accordingly.

WWTP plumes were sampled downstream of both sites twice. The plume from the Waterloo WWTP was sampled on 2007-10-30 (typical discharge 2-7 $\mathrm{m}^{3} / \mathrm{s}$ ) and 2008-07-01 (typical discharge 2-4 $\mathrm{m}^{3} / \mathrm{s}$ ). The plume from the Kitchener WWTP was sampled on 2007-10-23 (typical discharge 11-17 $\mathrm{m}^{3} / \mathrm{s}$ ) and 2008-07-18 (typical discharge $8-11 \mathrm{~m}^{3} / \mathrm{s}$ ).

\section{Analyses:}

Anion concentrations were measured on a Dionex ICS-90 ion chromatograph. Precisions and detection limits of $\mathrm{NO}_{3}{ }^{-}$were $0.07 \mathrm{mgN} / \mathrm{L}$ (standard deviation of 15 replicates of a standard solution) and $0.05 \mathrm{mgN} / \mathrm{L}$, respectively. $\mathrm{NO}_{2}{ }^{-}$concentrations were rarely detectable. Precision of $\mathrm{Cl}^{-}$ measurements was $<1 \mathrm{mg} / \mathrm{L}$. $\mathrm{NH}_{4}{ }^{+}$concentrations were measured colorimetrically by the phenate colourimetric method (EPA 350, (EPA 1993)) on a Beckman DU500 UV/VIS spectrophotometer with a precision and detection limit of $0.005 \mathrm{mgN} / \mathrm{L}$ and $0.015 \mathrm{mgN} / \mathrm{L}$, respectively.

$\delta^{15} \mathrm{~N}-\mathrm{TAN}$ was measured via the diffusion method on acidified discs(Zhang et al 2007). Briefly, $\mathrm{NH}_{4}^{+}$ is converted to $\mathrm{NH}_{3}$ by increasing the sample $\mathrm{pH} ; \mathrm{NH}_{3}$ is trapped in a filter pack containing a $1 \mathrm{~cm}$ GF/D filter, acidified with $\mathrm{H}_{2} \mathrm{SO}_{4}$, trapped in a PTFE packet. The filter is dried and analysed for $\delta^{15} \mathrm{~N}$ on a Carlo Erba 1108 elemental analyzer (EA) coupled to a Micromass Isochrom isotope-ratio mass spectrometer (IRMS). Precision of $\delta^{15} \mathrm{~N}_{-} \mathrm{NH}_{4}{ }^{+}$analysis was $\pm 0.3 \%$. $\delta^{15} \mathrm{~N}_{-} \mathrm{NO}_{3}{ }^{-}$was measured via the $\mathrm{AgNO}_{3}$ method. Briefly, sample volumes were reduced by evaporation, $\mathrm{SO}_{4}{ }^{2-}$ was removed by barium precipitation, and $\mathrm{NO}_{3}{ }^{-}$was collected on anion exchange resin in a column. After being eluted from the column, $\mathrm{AgO}$ was added to precipitate $\mathrm{AgNO}_{3}$, which was analyzed on the same EA-IRMS as above. Precision of $\delta^{15} \mathrm{~N}_{-\mathrm{NO}_{3}}{ }^{-}$was $\pm 0.5 \%$. Methodological tests indicated that the $\mathrm{AgNO}_{3}$ method can capture $\mathrm{NO}_{2}^{-}$since $\mathrm{NO}_{2}{ }^{-}$oxidizes rapidly to $\mathrm{NO}_{3}{ }^{-}$even in filtered samples.(Spoelstra 2004) Since previous measurements showed there was little $\mathrm{NO}_{2}^{-}$in this river $\left(\mathrm{NO}_{2}^{-}\right.$was $<5 \%$ of $\left.\mathrm{NO}_{3}^{-}\right)$the results presented here can be interpreted as $\delta^{15} \mathrm{~N}_{-} \mathrm{NO}_{3}{ }^{-}$.

\section{Model Setup}

To interpret patterns in the data, a dynamic model (hereafter NANNO: nitrate, ammonia, nitrite, nitrous oxide) was developed to describe the dynamics of TAN, $\mathrm{NO}_{2}^{-}, \mathrm{NO}_{3}{ }^{-}, \mathrm{N}_{2} \mathrm{O}$ and their $\delta^{15} \mathrm{~N}$ values (eight states, in total). The model was implemented in R(R Core Team 2016) using the simecol 
166 (Petzoldt and Rinke 2007) package. Five processes were modelled: volatilization of $\mathrm{NH}_{3}$, two-step 167 nitrification $\left(\mathrm{NH}_{4}{ }^{+} \rightarrow \mathrm{NO}_{2}{ }^{-}\right.$and $\left.\mathrm{NO}_{2}{ }^{-} \rightarrow \mathrm{NO}_{3}{ }^{-}\right)$, though see complete ammonia oxidation by a single 168 organism (comammox (van Kessel et al 2015)), denitrification $\left(\mathrm{NO}_{3}{ }^{-} \rightarrow \mathrm{N}_{2} \mathrm{O}\right.$ ), and biological 169 assimilation of $\mathrm{NH}_{4}^{+}$(Figure 2). In the model, $\mathrm{N}_{2} \mathrm{O}$ produced by denitrification is allowed to 170 accumulate rather than being further reduced to $\mathrm{N}_{2}$; this choice was made because the $\mathrm{N}_{2} \mathrm{O}: \mathrm{N}_{2}$ ratio 171 produced during denitrification varies widely and once nitrogen is removed from the TAN and $\mathrm{NO}_{3}$

172 pools, it is very unlikely to return to those pools especially in a system where $\mathrm{N}$ is in excess. Similarly, 173 the biological assimilation of $\mathrm{NO}_{3}{ }^{-}$was not included given that $\mathrm{NH}_{4}{ }^{+}$is in excess. Metabolic costs 174 suggest $\mathrm{NH}_{4}{ }^{+}$is the preferred source of nitrogen over $\mathrm{NO}_{3}{ }^{-}$for phytoplankton and aquatic plant(Mariotti 175 et al 1982, Yoneyama et al 1991, Collier et al 2012) and that cycling of $\mathrm{NH}_{4}{ }^{+}$uptake is rapid 176 (Mulholland et al 2000). Isotopic evidence suggests this is also true for macrophytes in the Grand 177 River, Ontario(Hood 2012, Hood et al 2014). Each process is associated with isotopic fractionation ( $\varepsilon$, 178 where $\varepsilon=\alpha-1$ and $\left.\alpha=\mathrm{R}_{\text {product }} / \mathrm{R}_{\text {reactant }}\right)$. Fractionation factors for physical processes are typically known 179 with greater precision than biological ones. Since the Grand River is very well buffered, average 180 measured $\mathrm{pH}$ values were used for TAN speciation calculations. Model parameters and commonly 181 reported values are summarized in Table 1.

182 To simplify modelling efforts, the common time-for-distance substitution was made. Additionally, to 183 avoid requiring river surface area for gas exchange with the atmosphere, all rate constants, including 184 the gas exchange coefficient, were modelled with units of per time. First-order rate kinetics were used 185 for nitrification (Chen et al 2006, Dinçer and Karg1 2000), $\mathrm{NH}_{4}{ }^{+}$uptake (MacIsaac and Dugdale 1969, 186 D'Elia and DeBoer 1978), and denitrification (Dinçer and Karg 12000 ). $\mathrm{NH}_{3}$ gas exchange was 187 modelled with the thin-boundary layer equation(Denmead and Freney 1992) assuming the atmospheric $188 \mathrm{NH}_{3}$ concentration was negligible (ppb-range range concentration (Finlayson-Pitts and Pitts 1986, 189 Mészáros 1992)). Ranges of potential gas exchange coefficients can be estimated from river channel 190 geometr(Raymond et al 2012) and converted for use with $\mathrm{NH}_{3}$ via Schmidt number scaling (Jähne et al 191 1987) (for example, at $20^{\circ} \mathrm{C}$ the Schmidt number for $\mathrm{NH}_{3}$ in freshwater is 585 (Kreith 2000).)

192 For the Grand River, the gas exchange coefficient for $\mathrm{O}_{2}$ has been estimated for its length with focus 193 on the areas including the WWTPs (Jamieson et al 2013, Venkiteswaran et al 2015). There $\mathrm{k}_{\mathrm{ge}}$ values 194 for $\mathrm{O}_{2}$ were $0.1-0.5 \mathrm{~m} / \mathrm{h}$. Measured river depths at all sampling sites were $0.5-1.0 \mathrm{~m}$. Modelled river 
195 velocities were $0.2-0.4 \mathrm{~m} / \mathrm{s}$ for typical flow conditions (MJ Anderson, pers. comm.). This produces a

196 range of $\mathrm{kg}_{\mathrm{ge}}$ values for $\mathrm{NH}_{3}$ of $0.0001-0.0006 \mathrm{~m}^{-1}$ downstream of the WWTPs.

197 An initial best-fit solution for each set of field data was found by allowing the model to find a

198 combination of rate constants (greater than or equal to 0), isotopic fractionation factors (between the

199 lowest literature $\alpha$ values, i.e. the strongest values, and 1), and initial values that minimized the sum of 200 squared errors between field data and model output.

$201 \quad$ Results:

\section{Field measures of $N$ concentrations and isotopes in WWTP plumes}

\section{Waterloo}

On both dates, TAN concentrations declined from $5-7 \mathrm{mgN} / \mathrm{L}$ to $\ll 1 \mathrm{mgN} / \mathrm{L}$ by the $5 \mathrm{~km}$ sampling point, although the rate of decline was much faster on 2008-07-01 than on 2007-10-30. Nitrate response in the plumes was different on both dates: on 2007-10-30, there was a gradual decline in $\mathrm{NO}_{3}^{-}$ but on 2008-07-01 there was an increase of $>1 \mathrm{mgN} / \mathrm{L}$. Together, these results suggests different fates for $\mathrm{N}$ in the Waterloo plume on each date.

On $2007-10-30, \delta^{15} \mathrm{~N}-\mathrm{TAN}$ values increase rapidly from $12 \%$ to $30 \%$ in the first $500 \mathrm{~m}$ before concentrations became too low for analyses. On 2008-07-01, there were no data below the initial sample but TAN persists at a greater distance downstream that on 2007-10-30. On both dates, the

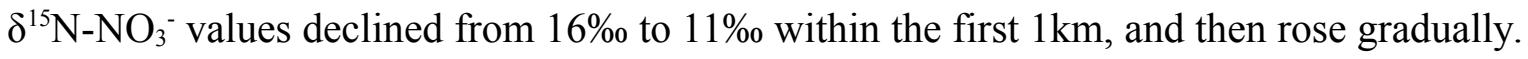

\section{Kitchener}

TAN concentrations downstream of the Kitchener WWTP declined to $<1 \mathrm{mgN} / \mathrm{L}$ over the $5.5 \mathrm{~km}$ sampling transect from initial values of $14 \mathrm{mgN} / \mathrm{L}$ and $4 \mathrm{mgN} / \mathrm{L}$ on 2007-10-23 and 2008-07-18.

Nitrate concentrations increased substantially on $2007-10-23$, from $0.8 \mathrm{mgN} / \mathrm{L}$ to $5.9 \mathrm{mgN} / \mathrm{L}$, and to a lesser degree on 2008-07-18 from $1.3 \mathrm{mgN} / \mathrm{L}$ to $3.1 \mathrm{mgN} / \mathrm{L}$.

$\delta^{15} \mathrm{~N}-\mathrm{TAN}$ values increased on both days, by $22 \%$ on $2007-10-23$ and by $12 \%$ on $2008-07-18$ over

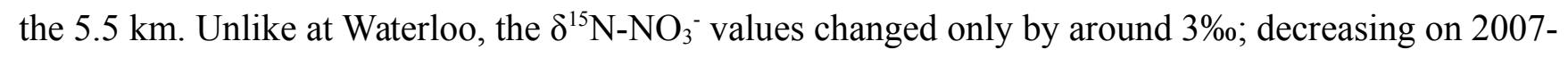
$10-23$ and increasing on 2008-07-18. 
223 The coupling of concentrations and isotopes in a simple process-based model shows that the various

$224 \mathrm{~N}$ cycling processes result in different patterns at the river scale. These results suggest the model may

225 reproduce the variety of expected patterns from each process in the model. Additionally, as we describe 226 next, the dynamic features of each process are sufficiently distinct that we would expect the model to 227 be identifiable. That is, we would expect to arrive at a tight estimate of the kinetic parameters given a 228 sufficiently rich field data set. If this were not the case, then there would be less likelihood that a 229 unique model solution describing TAN, $\mathrm{NO}_{2}{ }^{-}, \mathrm{NO}_{3}{ }^{-}, \mathrm{N}_{2} \mathrm{O}$ and their $\delta^{15} \mathrm{~N}$ values could be found.

230 Both $\mathrm{NH}_{3}$ degassing and $\mathrm{NH}_{4}{ }^{+}$uptake result in expected and rapid increases in $\delta^{15} \mathrm{~N}$ values but 231 increases in $\delta^{15} \mathrm{~N}$-TAN have different values with similar decreases in TAN due to the difference in 232 isotopic fractionation between the two processes. Nitrification alone produces a transient but small 233 increase in $\mathrm{NO}_{2}{ }^{-}(<20 \%$ of DIN at its greatest $)$ as $\mathrm{NH}_{4}{ }^{+}$is oxidized to $\mathrm{NO}_{3}{ }^{-}$. There is a characteristic 234 initial dip in $\delta^{15} \mathrm{~N}-\mathrm{NO}_{3}{ }^{-}$that must be a function of the initial $\delta^{15} \mathrm{~N}$ values and isotopic fractionation $\left(\alpha_{\text {nit }}\right.$ 235 and $\alpha_{n i t 2}$ ) and may be exploitable as an identifier of significant nitrification. Denitrification alone, 236 unlikely in a WWTP plume in a shallow oxygenated river during the day, results in a clear decline in $237 \mathrm{NO}_{3}{ }^{-}$associated with an increase in $\delta^{15} \mathrm{~N}_{-} \mathrm{NO}_{3}{ }^{-}$and no changes in TAN or $\delta^{15} \mathrm{~N}-\mathrm{TAN}$. There is a 238 corresponding increase in $\mathrm{N}_{2} \mathrm{O}$ and a transient dip in $\delta^{15} \mathrm{~N}-\mathrm{N}_{2} \mathrm{O}$ values that depends on initial conditions 239 and the strength of $\alpha_{\text {denit. }}$

240 An initial structural identifiability analysis (Bellman and Åström 1970) (see Supporting Information) 241 of the model dynamics and outputs confirmed that with the available data, it would not be possible to 242 separately estimate the rates at which the equilibrated TAN pool $\left(\mathrm{NH}_{3}\right.$ and $\left.\mathrm{NH}_{4}{ }^{+}\right)$is lost through gas 243 exchange and $\mathrm{NH}_{4}{ }^{+}$uptake processes. This conclusion is valid regardless of the quality of the 244 concentration data and $\delta^{15} \mathrm{~N}$ values (see also Supporting Information.)

245 Consequently, we simplified the model by fixing from independent sources the gas exchange 246 coefficient $\left(\mathrm{k}_{\mathrm{ge}}\right.$ (Venkiteswaran et al 2015, Jamieson et al 2013) and its isotope fractionation factor $\left(\alpha_{\mathrm{ge}}\right.$ 247 (Kirshenbaum et al 1947, Thode et al 1945, Norlin et al 2002).

248 We fit the resulting model separately to the four field data sets and then, in each case, applied 249 uncertainty analysis as described in Methods. The results varied, but from this preliminary analysis

250 (results not shown) we discovered that in every case the available data was not sufficient to provide 
251 accurate estimates of the 8 free parameters. In particular, the $k_{n i t}$ and $\alpha_{\text {nit2 }}$ parameters could not be well-

252 estimated from any of the datasets. Consequently, we reduced the model further, by removing $\mathrm{NO}_{2}{ }^{-}$and 253 instead describe a single-step nitrification process $\left(\mathrm{k}_{\text {nit1 }}\right.$ and $\left.\alpha_{\text {nit1 }}\right)$ where $\mathrm{NH}_{4}^{+}$is oxidized to $\mathrm{NO}_{3}{ }^{-}$;

254 justified given that $\mathrm{NO}_{2}{ }^{-}$concentrations are low compared to $\mathrm{NO}_{3}{ }^{-}$and TAN and not accumulating. The 255 resulting system has 6 states: TAN, $\mathrm{NO}_{3}{ }^{-}, \mathrm{N}_{2} \mathrm{O}, \delta^{15} \mathrm{~N}-\mathrm{TAN}, \delta^{15} \mathrm{~N}_{-} \mathrm{NO}_{3}{ }^{-}$, and $\delta^{15} \mathrm{~N}-\mathrm{N}_{2} \mathrm{O}$. Results of fitting 256 and uncertainty analysis, as described in Methods, are shown in the Supplementary Information Tables $2573-6$.

258 In the case of the Kitchener 2007 dataset (Supporting Information Table 6), the k parameters for 259 nitrification and denitrification all appear to be reasonably well constrained. The $\alpha$ estimates are less 260 confident. Two of the best-fit $\alpha$ value estimates, $\alpha_{\text {dnit }}$ and $\alpha_{\text {amup }}$, are at the bounds of the range of $\alpha$ 261 allowed (Table 1; $[0.975,1]$ ), suggesting the data provide minimal useful information about their 262 values. Moreover, while two of the sensitivities are not unreasonably low, the confidence intervals are 263 considerably larger than the search space, which has a width of only $2.5 \%(25 \%)$.

264 For the Kitchener 2008 best fit, the trend in certainty is similar but the data constrain the parameter 265 estimates to a lower degree. Data from Waterloo (2007 and 2008, Tables S4 and S5) provide even less 266 ability to constrain the rates likely because the system behaviour is not as dynamic, i.e. the range in $267 \delta^{15} \mathrm{~N}$ values is small despite the change in concentration being large.

\section{Discussion:}

The process-based NANNO model was able to reproduce the observed dynamics in concentrations and the $\delta^{15} \mathrm{~N}$ values of TAN and $\mathrm{NO}_{3}{ }^{-}$(Supporting Information Tables 3-6). Results from two seasons, with different proportional fates of $\mathrm{N}$ processing, at two different WWTPs with different TAN: $\mathrm{NO}_{3}{ }^{-}$ ratios in their effluent indicate a good degree of coherence between model results and field data (Figures 3-6 and Supplementary Tables 3-6.) Additionally, the shapes of the curves (increases, decreases, and pleateaux) were all generally reproducible by the model. The model was least successful in reproducing behaviour when there were increases in $\mathrm{NO}_{3}{ }^{-}$concentration without a change in $\delta^{15} \mathrm{~N}_{-} \mathrm{NO}_{3}{ }^{-}$. This scenario suggests nitrification where the new $\mathrm{NO}_{3}{ }^{-}$has the same $\delta^{15} \mathrm{~N}_{-} \mathrm{NO}_{3}{ }^{-}$as the extant $\mathrm{NO}_{3}^{-}$.

In all four cases, $\mathrm{N}$ is lost from the river downstream of the WWTPs. Rates for each N process can 
279 be summarized by their rate constants (Tables S4-S7) but are better compared as the mass of N

280 transformed by each process (Table 2). In three of four cases, $\mathrm{NH}_{3}$ loss via volatilization was much

281 lower than $\mathrm{NH}_{4}^{+}$loss via update or nitrification (Table 2). With river $\mathrm{pH}$ values of 7.6-8.4, well below

282 the $\mathrm{p} K_{\mathrm{a}}$ value of 9.4, and high rates of community metabolism (Venkiteswaran et al 2015, Jamieson et

283 al 2013) the N from WWTP effluent largely remained in and was transformed in the Grand River.

284 Previous work has shown that photosynthesis in the Grand River can be inhibited by high light in

285 summer (Chen et al 2014, Chen 2013) and autumn storms that serve to remove biomass may have

286 increased the availability of substrate for growth.

287 In both Waterloo cases, denitrification played a modest role in reducing $\mathrm{N}$ concentrations (Table 2).

$288 \mathrm{~N}_{2} \mathrm{O}$ concentrations in and fluxes from the Grand River are high downstream of these WWTPs

289 (Rosamond et al 2011, 2012, Venkiteswaran et al 2014). More detailed sampling of $\mathrm{N}_{2} \mathrm{O}$ and its $\delta^{15} \mathrm{~N}$

290 values may provide additional constraints to improve the model fit.

291 Nitrification played a moderate role in $\mathrm{N}$ cycling in all four cases. There were no clear correlations

292 between nitrification rates and rates of other $\mathrm{N}$ processes suggesting that predictions about the fate of $\mathrm{N}$

293 in the Grand River cannot be simply derived from other components of ecosystem metabolism. Where

294 measurable, $\mathrm{NO}_{2}{ }^{-}$concentrations and $\delta^{15} \mathrm{~N}$ values may provide additional information to the model by

295 constraining nitrification.

296 The $\delta^{15} \mathrm{~N}$ of benthic periphyton and invertebrate (Loomer 2008, Loomer et al 2014) as well as 297 macrophte (Hood 2012, Hood et al 2014) are often used as indicators of different N sources and N 298 pollution because they form the base of the food web. Interpreting these data requires an ability to 299 understand and predict the fate of large isotopically distinct N sources like WWTP effluent since the $300 \delta^{15} \mathrm{~N}$ values measured in biota ultimately depend on the source of $\mathrm{N}$ and isotopic fractionation during 301 uptake. Moreover, macrophytes integrate $\mathrm{N}$ over a much longer time scale than the effluent-plume 302 travel time or diel variability (Loomer et al 2014, Hood et al 2014).

303 There are several key model parameters that are insufficiently characterized, such as isotopic 304 fractionation during TAN and $\mathrm{NO}_{3}{ }^{-}$uptake, preferential uptake of different $\mathrm{N}$ species, and release of 305 TAN and $\mathrm{NO}_{3}^{-}$. The variability in isotopic fractionation during $\mathrm{NH}_{4}^{+}$uptake is large and varies non306 linearly with concentration (Hoch et al 1992, Pennock et al 1996, Yoneyama et al 2001). This poses a 307 vexing problem at the ecosystem scale since the isotopic enrichment - concentration relationship varies 
between species and both concentrations and species vary within ecosystems.

309 The mass and $\delta^{15} \mathrm{~N}$ of river biomass are difficult to capture in the parsimonious NANNO model structure; model fitting may be improved if the release of TAN and $\mathrm{NO}_{3}{ }^{-}$by biomass contributes

311 significantly to river N relative to WWTP effluent (Loomer et al 2014). Nitrogen uptake and release 312 rates can be estimated with nutrient spiralling techniques but this analysis often conflates TAN and $313 \mathrm{NO}_{3}^{-}$. It is therefore difficult to discern which $\mathrm{N}$ form is used, which is released, and how these results 314 apply to a river with more than $100 \mathrm{~km}$ of upstream nutrient inputs. The degree of importance, if any, to 315 dissolved organic $\mathrm{N}$ mineralization or $\mathrm{N}$ release from microbes and macrophytes in the nutrient-replete 316 WWTP plumes is unknown.

317 Understanding the ecosystem effects of changes in nitrogen sources, such as altering WWTPs to 318 produce only $\mathrm{NO}_{3}{ }^{-}$instead of $\mathrm{NH}_{4}{ }^{+}$in order to improve river $\mathrm{O}_{2}$ concentrations, requires knowledge 319 about which $\mathrm{N}$ enters the base of the foodweb via primary producers and consumers. In cases where $320 \delta^{15}{\mathrm{~N}-\mathrm{NO}_{3}}^{-}$and $\delta^{15} \mathrm{~N}-\mathrm{TAN}$ values are far enough apart, or one is changing while the other is constant, the 321 use of each by primary producers and consumers may be teased apart. $\mathrm{NO}_{3}{ }^{-}$uptake is associated with 322 little to no isotopic fractionation (Mariotti et al 1981, Yoneyama et al 1998, 2001) and in the WWTPs' 323 effluent plumes in the Grand River $\delta^{15} \mathrm{~N}_{-} \mathrm{NO}_{3}{ }^{-}$values do not vary as much as $\delta^{15} \mathrm{~N}-\mathrm{TAN}$ values. In such 324 scenarios, response to increasing $\delta^{15} \mathrm{~N}$-TAN may be observable as a concomitant increase in the $\delta^{15} \mathrm{~N}$ of 325 primary producers and consumers (Loomer et al 2014, Hood et al 2014).

326 Since $\mathrm{O}_{2}, \mathrm{~N}$, and phosphorus cycles are strongly linked, improving the understanding of nitrogen 327 processes allows previous work on $\mathrm{O}_{2}$ and phosphorus cycling in the Grand Rive(Barlow-Busch et al 328 2006, Venkiteswaran et al 2014, 2015) to be extended to process-based biogeochemical models that 329 incorporate multiple elements and their isotopes. Components that may be added to NANNO to 330 improve constraints on nitrogen processes include $\delta^{18} \mathrm{O}-\mathrm{NO}_{3}{ }^{-}$values. However, recent work has 331 demonstrated that predicting the $\delta^{18} \mathrm{O}$ values of nitrogenous species is more complicated than originally 332 thought because there are poorly understood abiotic factors that alter the $\delta^{18} \mathrm{O}$ value of $\mathrm{NO}_{2}^{-}$and $\mathrm{NO}_{3}^{-}$ 333 as well as multiple pathways to produce $\mathrm{N}_{2} \mathrm{O}$ (Snider et al 2010, 2012, 2013, 2015, Casciotti et al 2010, 334 Buchwald and Casciotti 2010, Buchwald et al 2012). Nevertheless, there are opportunities to produce a 335 more constrainable model.

336 We have presented a process based-isotopic model of key nitrogen species for use in nutrient plumes 
337 in rivers. The NANNO model successfully reproduced observed dynamics in TAN and $\mathrm{NO}_{3}^{-}$

338 concentrations and their $\delta^{15} \mathrm{~N}$ values including seasonal differences in the way $\mathrm{N}$ species were

339 processed. The ability to model these processes is a key step to making predictions about how

340 improvements in WWTP effluent will affect receiving waters.

341 Acknowledgements:

342 Canada's Natural Science and Engineering Research Council funded the field research under STPGP

343 336807-06 and STPGP 381058-09. Grand River Conservation Authority provided assistance with field

344 data. A portion of this was work performed while under the sponsorship of the International Atomic

345 Energy Agency Collaborative Research Program F32007. Field and laboratory assistance was provided 346 by Richard Elgood, Neus Otero, Marilla Murray, Sarah Sine, David Snider, Madeline Rosamond. We

347 thank Thomas Petzoldt for the ease with which the simecol package can be used and Hadley Wickham

348 and Winston Chang for their work on and documentation of ggplot2.

349 Author Contributions:

350 Conceived and designed the experiments: JJV, SLS. Performed the experiments: JJV, SLS. Analyzed 351 the results: JJV, BPI, SLS. Contributed reagents/materials/analysis tools: JJV, SLS, BPI. Wrote and 352 reviewed the paper: JJV, SLS, BPI.

\section{Data Deposition:}

354 Data and code are available as part of the NANNO package https://github.com/jjvenky/NANNO 355 (reviewers can anonymously review the code at this URL; upon the paper's acceptance, a DOI will be 356 obtained and used).

\section{References:}

Barlow-Busch L, Baulch H M and Taylor W D 2006 Phosphate uptake by seston and epilithon in the Grand River, southern Ontario Aquat. Sci. 68 181-92

Bellman R and Åström K J 1970 On structural identifiability Math. Biosci. 7 329-39

Buchwald C and Casciotti K L 2010 Oxygen isotopic fractionation and exchange during bacterial nitrite oxidation Limnol. Oceanogr. 55 1064-74

Buchwald C, Santoro A E, McIlvin M R and Casciotti K L 2012 Oxygen isotopic composition of nitrate 
and nitrite produced by nitrifying cocultures and natural marine assemblages Limnol. Oceanogr. 57 1361-75

Canadian Council of Ministers of the Environment 2010 Canadian water quality guidelines for the protection of aquatic life: ammonia Canadian environmental quality guidelines (Winnipeg: Canadian Council of Ministers of the Environment) Online: http://ceqgrcqe.ccme.ca/download/en/141/

Canadian Council of Ministers of the Environment 2012 Canadian water quality guidelines for the protection of aquatic life: nitrate ion Canadian environmental quality guidelines (Winnipeg: Canadian Council of Ministers of the Environment) Online: http://ceqgrcqe.ccme.ca/download/en/197/

Casciotti K L, Mcllvin M and Buchwald C 2010 Oxygen isotopic exchange and fractionation during bacterial ammonia oxidation Limnol. Oceanogr. 55 753-62

Chen G 2013 Ecosystem oxygen metabolism in an impacted temperate river network: Application of the $\delta^{18} O$-DO approach (University of Waterloo) Online: http://hdl.handle.net/10012/7412

Chen G, Venkiteswaran J J, Schiff S L and Taylor W D 2014 Inverse modeling of dissolved $\mathrm{O}_{2}$ and $\delta^{18} \mathrm{O}-\mathrm{DO}$ to estimate aquatic metabolism, reaeration and respiration isotopic fractionation: effects of variable light regimes and input uncertainties Aquat. Sci. 76 313-29

Chen S, Ling J and Blancheton J-P 2006 Nitrification kinetics of biofilm as affected by water quality factors Aquac. Eng. 34 179-97

Collier J L, Lovindeer R, Xi Y, Radway J C and Armstrong R A 2012 Differences in Growth and Physiology of Marine Synechococcus (Cyanobacteria) on Nitrate Versus Ammonium Are Not Determined Solely By Nitrogen Source Redox State J. Phycol. 48 106-16

Davis C J and Minshall W G 1999 Nitrogen and phosphorus uptake in two Idaho (USA) headwater wilderness streams Oecologia 119 247-55

D’Elia C F and DeBoer J A 1978 Nutritional Studies of Two Red Algae. II. Kinetic of Ammonium and Nitrate Uptake J. Phycol. 14 266-72

Delwiche C C and Steyn P L 1970 Nitrogen isotope fractionation in soils and microbial reactions Environ. Sci. Technol. 4 929-35

Denk T R A, Mohn J, Decock C, Lewicka-Szczebak D, Harris E, Butterbach-Bahl K, Kiese R and Wolf B 2017 The nitrogen cycle: A review of isotope effects and isotope modeling approaches Soil Biol. Biochem. 105 121-37

Denmead O T and Freney J R 1992 Transfer Coefficients for Water-Air Exchange of Ammonia, Carbon Dioxide and Methane Ecol. Bull. 42 31-41 
Derse E, Knee K L, Wankel S D, Kendall C, Berg, C J and Paytan A 2007 Identifying Sources of Nitrogen to Hanalei Bay, Kauai, Utilizing the Nitrogen Isotope Signature of Macroalgae Environ. Sci. Technol. 41 5217-23

Dinçer A R and Karg1 F 2000 Kinetics of sequential nitrification and denitrification processes Enzyme Microb. Technol. 27 37-42

Dodds W K K and Welch E B 2000 Establishing nutrient criteria in streams J. North Am. Benthol. Soc. 19 186-96

Earl S R, Valett H M and Webster J R 2006 Nitrogen Saturation in Stream Ecosystems Ecology 87 3140-51

EPA 1993 Method 350.1: Determination of Ammonia Nitrogen by Semi-Automated Colorimetry. Revision 2.0 Online: https:/www.epa.gov/sites/production/files/2015-06/documents/epa350.1.pdf

Finlayson-Pitts B J and Pitts J N Jr 1986 Atmospheric Chemistry: Fundamentals and Experimental Techniques (New York)

Fogel M L and Cifuentes L A 1993 Isotope fractionation during primary production Organic geochemistry ed H M Engel and S A Macko (New York: Plenum Press) pp 73-98

Fourqurean J, Moore T, Fry B and Hollibaugh J 1997 Spatial and temporal variation in C:N:P ratios, $\delta^{15} \mathrm{~N}$, and $\delta^{13} \mathrm{C}$ of eelgrass Zostera marina as indicators of ecosystem processes, Tomales Bay, California, USA Mar. Ecol. Prog. Ser. 157 147-57

Fry B, Bern A L, Ross M S and Meeder J F $2000 \delta^{15} \mathrm{~N}$ Studies of Nitrogen Use by the Red Mangrove, Rhizophora mangle L. in South Florida Estuar. Coast. Shelf Sci. 50 291-6

Gammons C H, Babcock J N, Parker S R and Poulson S R 2010 Diel cycling and stable isotopes of dissolved oxygen, dissolved inorganic carbon, and nitrogenous species in a stream receiving treated municipal sewage Chem. Geol.

Hall R J O and Tank J L 2003 Ecosystem metabolism controls nitrogen uptake in streams in Grand Teton National Park, Wyoming Limnol. Oceanogr. 48 1120-8

Hall R O, Tank J L, Sobota D J, Mulholland P J, O'Brien J M, Dodds W K, Webster J R, Valett H M, Poole G C, Peterson B J, Meyer J L, McDowell W H, Johnson S L, Hamilton S K, Grimm N B, Gregory S V, Dahm C N, Cooper L W, Ashkenas L R, Thomas S M, Sheibley R W, Potter J D, Niederlehner B R, Johnson L T, Helton A M, Crenshaw C M, Burgin A J, Bernot M J, Beaulieu $\mathrm{J} J$ and Arangob C P 2009 Nitrate removal in stream ecosystems measured by $15 \mathrm{~N}$ addition experiments: Total uptake Limnol. Oceanogr. 54 653-65

Hermes J D, Weiss P M and Cleland W W 1985 Use of nitrogen-15 and deuterium isotope effects to determine the chemical mechanism of phenylalanine ammonia-lyase Biochemistry (Mosc.) 24 
Hoch M P, Fogel M L and Kirchman D L 1992 Isotope fractionation associated with ammonium uptake by a marine bacterium Limnol. Oceanogr. 371447

Holtgrieve G W, Schindler D E, Branch T A and A'mar Z T 2010 Simultaneous quantification of aquatic ecosystem metabolism and reaeration using a Bayesian statistical model of oxygen dynamics Limnol. Oceanogr. 55 1047-63

Hood J L A 2012 The role of submersed macrophytes in river eutrophication and biogeochemical nutrient cycling (University of Waterloo) Online: http://hdl.handle.net/10012/7084

Hood J L A, Taylor W D and Schiff S L 2014 Examining the fate of WWTP effluent nitrogen using $\delta^{15} \mathrm{~N}-\mathrm{NH}_{4}{ }^{+}, \delta^{15} \mathrm{~N}-\mathrm{NO}_{3}{ }^{-}$and $\delta^{15} \mathrm{~N}$ of submersed macrophytes Aquat. Sci. 76 243-58

Iwanyshyn M, Ryan M C and Chu A 2008 Separation of physical loading from photosynthesis/respiration processes in rivers by mass balance Sci. Total Environ. 390 205-14

Jähne B, Münnich K O, Bösinger R, Dutzi A, Huber W and Libner P 1987 On the parameters influencing air-water gas exchange J. Geophys. Res. Oceans 92 1937-49

Jamieson T S, Schiff S L and Taylor W D 2013 Using stable isotopes of dissolved oxygen for the determination of gas exchange in the Grand River, Ontario, Canada. Water Res 47 781-90

Karrow P F 1974 Till Stratigraphy in Parts of Southwestern Ontario Geol. Soc. Am. Bull. 85761

van Kessel M A H J, Speth D R, Albertsen M, Nielsen P H, Op den Camp H J M, Kartal B, Jetten M S $\mathrm{M}$ and Lücker S 2015 Complete nitrification by a single microorganism Nature Online: http://www.nature.com/doifinder/10.1038/nature16459

Kirshenbaum I, Smith J S, Crowell T, Graff J and McKee R 1947 Separation of the Nitrogen Isotopes by the Exchange Reaction between Ammonia and Solutions of Ammonium Nitrate J. Chem. Phys. 15 440-6

Kreith F 2000 The CRC handbook of thermal engineering (Springer Science \& Business Media)

Laursen A E and Seitzinger S P 2004 Diurnal patterns of denitrification, oxygen consumption and nitrous oxide production in rivers measured at the whole-reach scale Freshw. Biol. 49 1448-58

Laursen A E and Seitzinger S P 2002 Measurement of denitrification in rivers: an integrated, whole reach approach Hydrobiologia $\mathbf{4 8 5}$ 67-81

Li L, Lollar B S, Li H, Wortmann U G and Lacrampe-Couloume G 2012 Ammonium stability and nitrogen isotope fractionations for $\mathrm{NH}_{4}{ }^{+}-\mathrm{NH}_{3(\mathrm{aq})}-\mathrm{NH}_{3 \text { (gas) }}$ systems at $20-70^{\circ} \mathrm{C}$ and $\mathrm{pH}$ of 2-13: Applications to habitability and nitrogen cycling in low-temperature hydrothermal systems Geochim. Cosmochim. Acta $\mathbf{8 4}$ 280-96 
Loomer H A 2008 The Dynamics of Carbon and Nitrogen Stable Isotope Analysis of Aquatic

Organisms within the Grand River Watershed (University of Waterloo) Online:

http://hdl.handle.net/10012/4263

Loomer H A, Oakes K D, Schiff S L, Taylor W D and Servos M R 2014 Use of Stable Isotopes to Trace Municipal Wastewater Effluents into Food Webs within a Highly Developed River System River Res. Appl. 31 1093-100

MacIsaac J J and Dugdale R C 1969 The kinetics of nitrate and ammonia uptake by natural populations of marine phytoplankton Deep Sea Res. Oceanogr. Abstr. 16 45-57

Mariotti A, Germon J C, Hubert P, Kaiser P, Letolle R, Tardieux A and Tardieux P 1981 Experimental determination of nitrogen kinetic isotope fractionation: Some principles; illustration for the denitrification and nitrification processes Plant Soil 62413

Mariotti A, Mariotti F, Champigny M-L, Amarger N and Moyse A 1982 Nitrogen Isotope Fractionation Associated with Nitrate Reductase Activity and Uptake of $\mathrm{NO}_{3}{ }^{-}$by Pearl Millet Plant Physiol. $69880-4$

Mészáros E 1992 Occurrence of Atmospheric Acidity Atmospheric Acidity: Sources, Consequences and Abatement Elsevier Handling and Processing of Solids Series ed M Radojevic and R M Harrison (Springer) pp 1-38 Online: https://books.google.ca/books?id=aU3i3TEk8nYC

Mulholland P J, Helton A M, Poole G C, Hall R O, Hamilton S K, Peterson B J, Tank J L, Ashkenas L R, Cooper L W, Dahm C N, Dodds W K, Findlay S E G, Gregory S V, Grimm N B, Johnson S L, McDowell W H, Meyer J L, Valett H M, Webster J R, Arango C P, Beaulieu J J, Bernot M J, Burgin A J, Crenshaw C L, Johnson L T, Niederlehner B R, O’Brien J M, Potter J D, Sheibley R W, Sobota D J and Thomas S M 2008 Stream denitrification across biomes and its response to anthropogenic nitrate loading. Nature 452 202-5

Mulholland P J, Tank J L, Sanzone D M, Wollheim W M, Peterson B J, Webster J R and Meyer J L 2000 Nitrogen Cycling in a Forest Stream Determined by a ${ }^{15} \mathrm{~N}$ Tracer Addition Ecol. Monogr. 70 471-93

Mulholland P J, Valett H M, Webster J R, Thomas S A, Cooper L W, Hamilton S K and Peterson B J 2004 Stream denitrification and total nitrate uptake rates measured using a field ${ }^{15} \mathrm{~N}$ tracer addition approach Limnol. Oceanogr. 49 809-20

Murray M 2008 Evaluating the isotopic fingerprint of wastewater treatment plant nitrogen and its evolution in the Grand River (University of Waterloo)

Newbold J D, Elwood J W, O’Neill R V and Sheldon A L 1983 Phosphorus Dynamics in a Woodland Stream Ecosystem: A Study of Nutrient Spiralling Ecology 64 1249-65

Newbold J D, Elwood J W, O’Neill R V and Winkle W V 1981 Measuring Nutrient Spiralling in Streams Can. J. Fish. Aquat. Sci. 38 860-3 
Newbold J, O'neill R, Elwood J and Van Winkle W 1982 Nutrient Spiralling in Streams: Implications for Nutrient Limitation and Invertebrate Activity Am. Nat. 120 628-52

Norlin E, Irgum K and Ohlsson K E A 2002 Determination of the ${ }^{15} \mathrm{~N} /{ }^{14} \mathrm{~N}$ ratio of ammonium and ammonia in aqueous solutions by equilibrium headspace-gas chromatography-combustionisotope ratio mass spectrometry The Analyst 127 735-40

Olofsson G 1975 Thermodynamic quantities for the dissociation of the ammonium ion and for the ionization of aqueous ammonia over a wide temperature range J. Chem. Thermodyn. 7507

Parker S R, Gammons C H, Poulson S R, DeGrandpre M D, Weyer C L, Smith M G, Babcock J N and Oba Y 2010 Diel behavior of stable isotopes of dissolved oxygen and dissolved inorganic carbon in rivers over a range of trophic conditions, and in a mesocosm experiment Chem. Geol. $26922-32$

Peipoch M, Gacia E, Blesa A, Ribot M, Riera J L and Martí E 2014 Contrasts among macrophyte riparian species in their use of stream water nitrate and ammonium: insights from ${ }^{15} \mathrm{~N}$ natural abundance Aquat. Sci. 76 203-15

Pennock J R, Velinsky D J, Ludlam J M, Sharp J H and Fogel M L 1996 Isotopic fractionation of ammonium and nitrate during uptake by Skeletonema costatum: Implications for $\delta^{15} \mathrm{~N}$ dynamics under bloom conditions Limnol. Oceanogr. 41451

Petzoldt T and Rinke K 2007 simecol: An Object-Oriented Framework for Ecological Modeling in R $J$. Stat. Softw. 221

Posch M, de Smet P A M, Hettelingh J P and Downing R J 2001 Modelling and mapping of critical thresholds in Europe RIVM Rapp. 259101010

R Core Team 2016 R: A Language and Environment for Statistical Computing (Vienna, Austria: R Foundation for Statistical Computing) Online: https:/www.R-project.org/

Raymond P A, Zappa C J, Butman D, Bott T L, Potter J, Mulholland P, Laursen A E, McDowell W H and Newbold D 2012 Scaling the gas transfer velocity and hydraulic geometry in streams and small rivers Limnol. Oceanogr. Fluids Environ. 241

Region of Waterloo 2011 Residential Water Softener Performance Study. Testing Report \#1 (Waterloo, Ontario, Canada: Region of Waterloo) Online:

http://www.regionofwaterloo.ca/en/aboutTheEnvironment/resources/WaterSoftenerReportApril 2011.pdf

Rosamond M S, Thuss S J and Schiff S L 2012 Dependence of riverine nitrous oxide emissions on dissolved oxygen levels Nat. Geosci. 5 715-8

Rosamond M S, Thuss S J, Schiff S L and Elgood R J 2011 Coupled Cycles of Dissolved Oxygen and Nitrous Oxide in Rivers along a Trophic Gradient in Southern Ontario, Canada J. Environ. 


\section{Qual. 40 256-70}

Savage C and Elmgren R 2004 Macroalgal (Fucus vesiculosus) $\delta^{15} \mathrm{~N}$ Values Trace Decrease in Sewage Influence Ecol. Appl. 14 517-26

Schindler D W 1998 Whole-Ecosystem Experiments: Replication Versus Realism: The Need for Ecosystem-Scale Experiments Ecosystems $1323-34$

Schindler D W, Dillon P J and Schreier H 2006 A review of anthropogenic sources of nitrogen and their effects on Canadian aquatic ecosystems Biogeochemistry 79 25-44

Sebilo M, Billen G, Grably M and Mariotti A 2003 Isotopic composition of nitrate-nitrogen as a marker of riparian and benthic denitrification at the scale of the whole Seine River system Biogeochemistry 6335

Sharpley A N, Kleinman P J A, Jordan P, Bergström L and Allen A L 2009 Evaluating the Success of Phosphorus Management from Field to Watershed J. Environ. Qual. 381981

Snider D M, Spoelstra J, Schiff S L and Venkiteswaran J J 2010 Stable Oxygen Isotope Ratios of Nitrate Produced from Nitrification: ${ }^{18} \mathrm{O}-$ Labeled Water Incubations of Agricultural and Temperate Forest Soils Environ. Sci. Technol. 44 5358-64

Snider D M, Venkiteswaran J J, Schiff S L and Spoelstra J 2013 A new mechanistic model of $\delta^{18} \mathrm{O}-\mathrm{N}_{2} \mathrm{O}$ formation by denitrification Geochim. Cosmochim. Acta 112 102-15

Snider D M, Venkiteswaran J J, Schiff S L and Spoelstra J 2012 Deciphering the oxygen isotope composition of nitrous oxide produced by nitrification Glob. Change Biol. 18 356-70

Snider D M, Venkiteswaran J J, Schiff S L and Spoelstra J 2015 From the Ground Up: Global Nitrous Oxide Sources are Constrained by Stable Isotope Values ed S Hu PLOS ONE 10 e0118954

Spoelstra J 2004 Nitrate sources and cycling at the Turkey Lakes Watershed: A stable isotope approach $\mathrm{PhD}$ thesis (Waterloo, Canada: University of Waterloo) Online:

http://hdl.handle.net/10012/1240

Tank J L, Meyer J L, Sanzone D M, Mulholland P J, Webster J R, Peterson B J, Wollheim W M and Leonard N E 2000 Analysis of nitrogen cycling in a forest stream during autumn using a ${ }^{15} \mathrm{~N}-$ tracer addition Limnol. Oceanogr. 45 1013-29

Thode H G, Graham R L and Ziegler J A 1945 A Mass Spectrometer and the Measurement of Isotope Exchange Factors Can. J. Res. 23b 40-7

Thuss S J, Venkiteswaran J J and Schiff S L 2014 Proper interpretation of dissolved nitrous oxide isotopes, production pathways, and emissions requires a modelling approach. PLOS ONE 9 e90641 
Tobias C R, Böhlke J K and Harvey J W 2007 The oxygen-18 isotope approach for measuring aquatic metabolism in high productivity waters Limnol. Oceanogr. 52 1439-53

Venkiteswaran J J, Rosamond M S and Schiff S L 2014 Nonlinear Response of Riverine $\mathrm{N}_{2} \mathrm{O}$ Fluxes to Oxygen and Temperature Environ. Sci. Technol. 48 1566-73

Venkiteswaran J J, Schiff S L and Taylor W D 2015 Linking aquatic metabolism, gas exchange, and hypoxia to impacts along the 300-km Grand River, Canada Freshw. Sci. 34 1216-32

Venkiteswaran J J, Wassenaar L I and Schiff S L 2007 Dynamics of dissolved oxygen isotopic ratios: a transient model to quantify primary production, community respiration, and air-water exchange in aquatic ecosystems Oecologia 153 385-98

Wassenaar L I, Venkiteswaran J J, Schiff S L and Koehler G 2010 Aquatic community metabolism response to municipal effluent inputs in rivers quantified using diel $\delta^{18} \mathrm{O}$ values of dissolved oxygen Can. J. Fish. Aquat. Sci. 67 1232-46

Webster J R, Mulholland P J, Tank J L, Valett H M, Dodds W K, Peterson B J, Bowden W B, Dahm C N, Findlay S, Gregory S V, Grimm N B, Hamilton S K, Johnson S L, Marti E, Mcdowell W H, Meyer J L, Morrall D D, Thomas S A and Wollheim W M 2003 Factors affecting ammonium uptake in streams - an inter-biome perspective Freshw. Biol. 48 1329-52

Withers P J . and Lord E I 2002 Agricultural nutrient inputs to rivers and groundwaters in the UK: policy, environmental management and research needs Sci. Total Environ. 282-283 9-24

Yoneyama T, Fujihara S and Yagi K 1998 Natural abundance of ${ }^{15} \mathrm{~N}$ in amino acids and polyamines from leguminous nodules: unique ${ }^{15} \mathrm{~N}$ enrichment in homospermidine J. Exp. Bot. 49521

Yoneyama T, Matsumaru T, Usui K and Engelaar W M H G 2001 Discrimination of nitrogen isotopes during absorption of ammonium and nitrate at different nitrogen concentrations by rice (Oryza sativa L.) plants Plant Cell Environ. 24133

Yoneyama T, Omata T, Nakata S and Yazaki J 1991 Fractionation of Nitrogen Isotopes during the Uptake and Assimilation of Ammonia by Plants Plant Cell Physiol. 32 1211-7

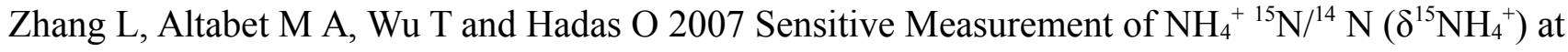
Natural Abundance Levels in Fresh and Saltwaters Anal. Chem. 79 5297-303 


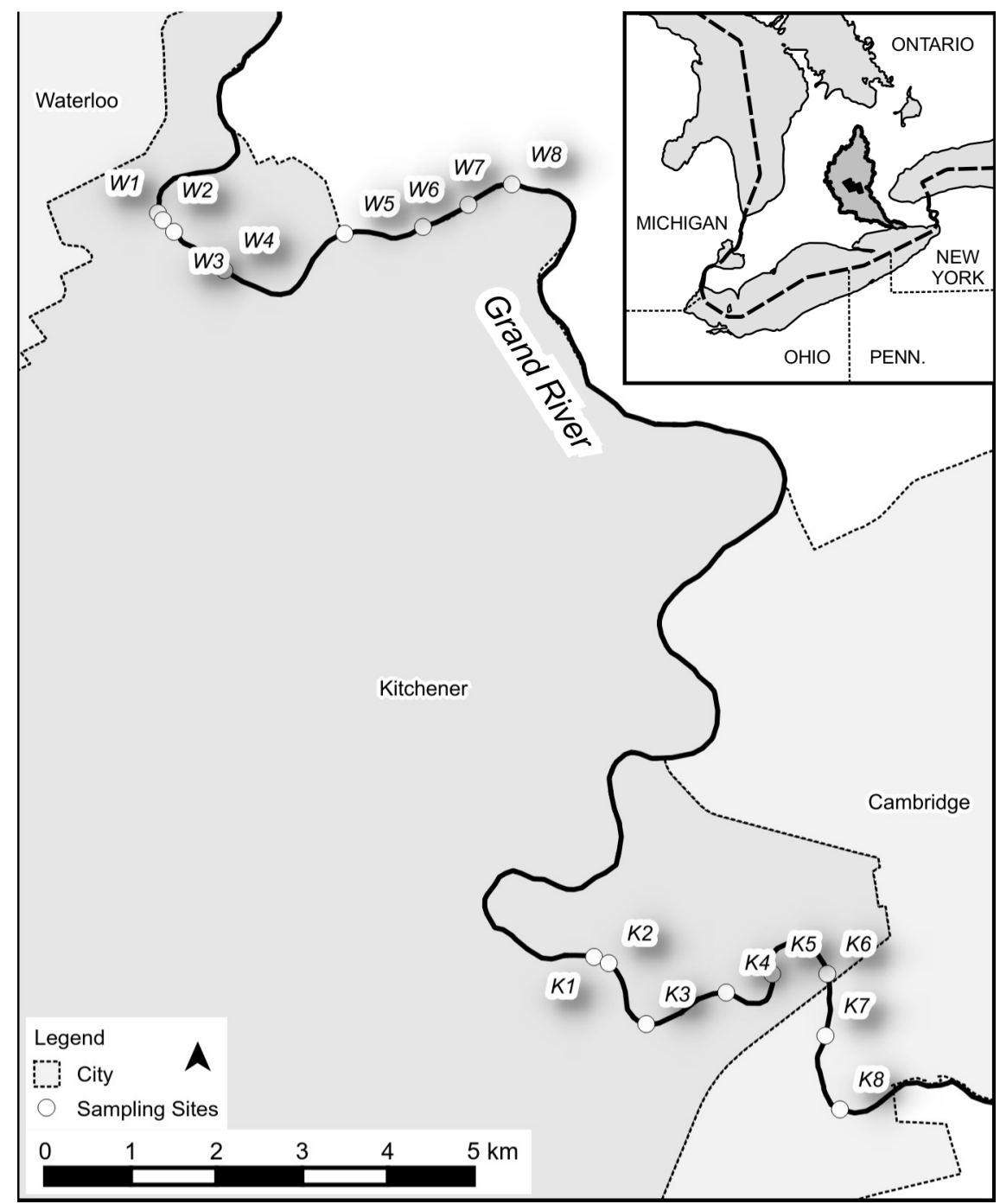

360 1. Central portion of the Grand River watershed in south-western Ontario, Canada. River flow is

361 from north to south. Sampling sites below the Waterloo (W) and Kitchener (K) waste-water treatment

362 plants are numbered 1-8. The cities of Cambridge, Kitchener, and Waterloo are highlighted as black

363 blocks in the middle of the Grand River watershed in the inset map. Made with Natural Earth data

364 (naturalearthdata.com) and information under licence with the Grand River Conservation Authority. 


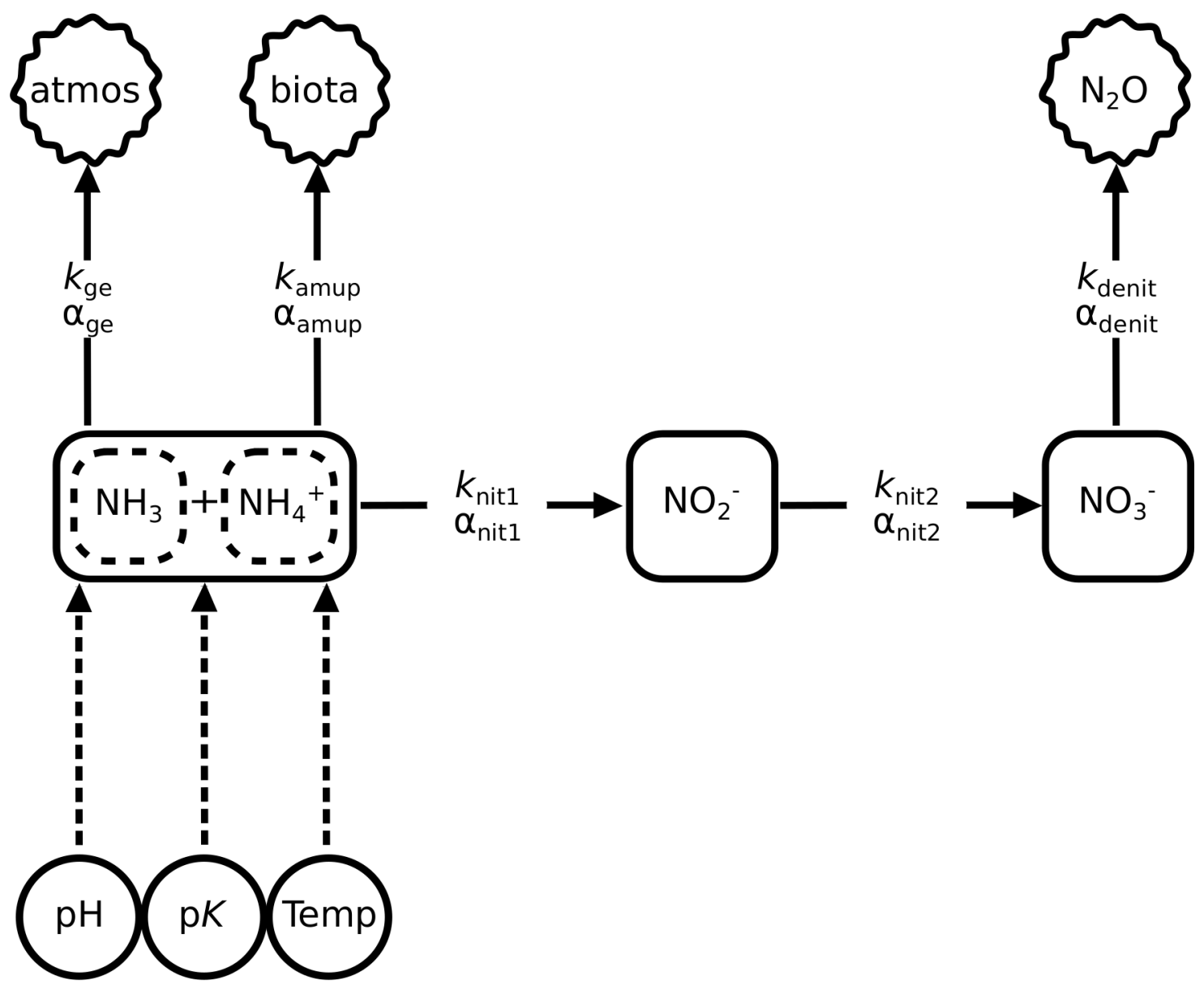

366 2. Nitrogen pathways in the eight-state NANNO model. Each box represents represents a stock or 367 pool. Circles represent data inputs to the model. Flows of nitrogen between stocks are identified with 368 arrows, accompanied by first-order rate constants, $k$. Clouds indicate a loss of nitrogen from the 369 system. Total ammonia nitrogen is modelled as ammonia $\left(\mathrm{NH}_{3}\right)$ and ammonium $\left(\mathrm{NH}_{4}{ }^{+}\right)$. The ratio is set 370 by measured temperature and $\mathrm{pH}$, and calculated $\mathrm{p} K$ values. Ammonia gas exchange (ge) is modelled 371 via the thin boundary layer model (Denmead and Freney 1992). Ammonium assimilation (amup) by 372 biota is modelled as a loss of $\mathrm{NH}_{4}{ }^{+}$. Two-step nitrification (nit1, nit2) is modelled as $\mathrm{NH}_{4}{ }^{+}$to $\mathrm{NO}_{2}{ }^{-}$to $373 \mathrm{NO}_{3}^{-}$. Denitrification (denit) is modelled as a loss of $\mathrm{NO}_{3}{ }^{-}$to $\mathrm{N}_{2} \mathrm{O}$. Each stock is modelled 374 independently for each isotope and flows are adjusted by isotope fractionation factors $(\alpha)$. 

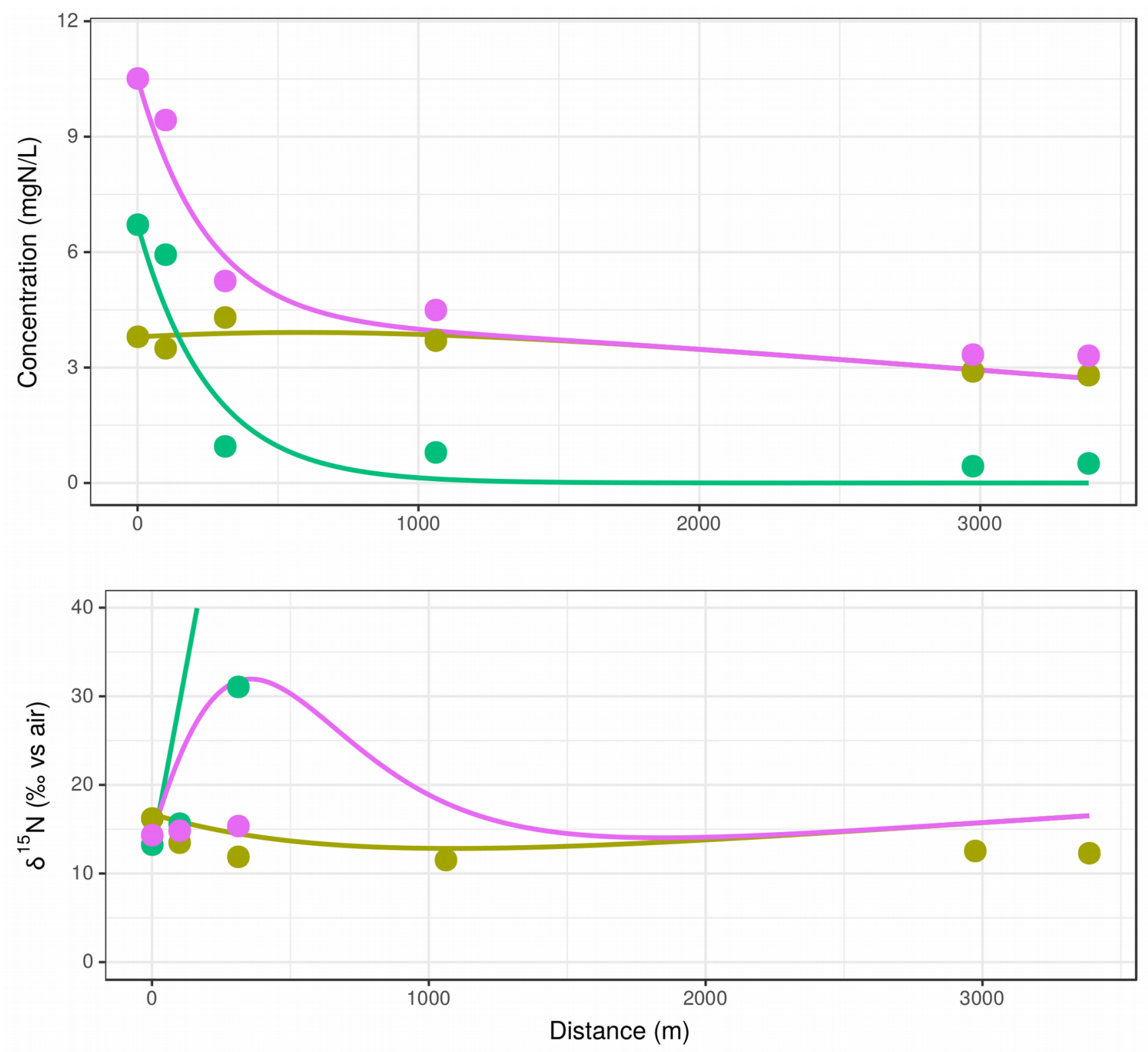

375 3. Waterloo wastewater treatment plants plumes on 2007-10-30. Measured field data (adjusted for 376 WWTP plume dilution using $\mathrm{Cl}^{-}$data) are shown as points. Best-fit model results are shown as curves.

377 Parameters used in the model are given in Table 1. Dissolved inorganic nitrogen (DIN $=\mathrm{TAN}+\mathrm{NO}_{3}^{-}$

378 and mass-weighted $\delta^{15} \mathrm{~N}-\mathrm{DIN}$ ) is also plotted to show where there is $\mathrm{N}$ loss from the system either 379 through degassing, assimilation or denitrification. 

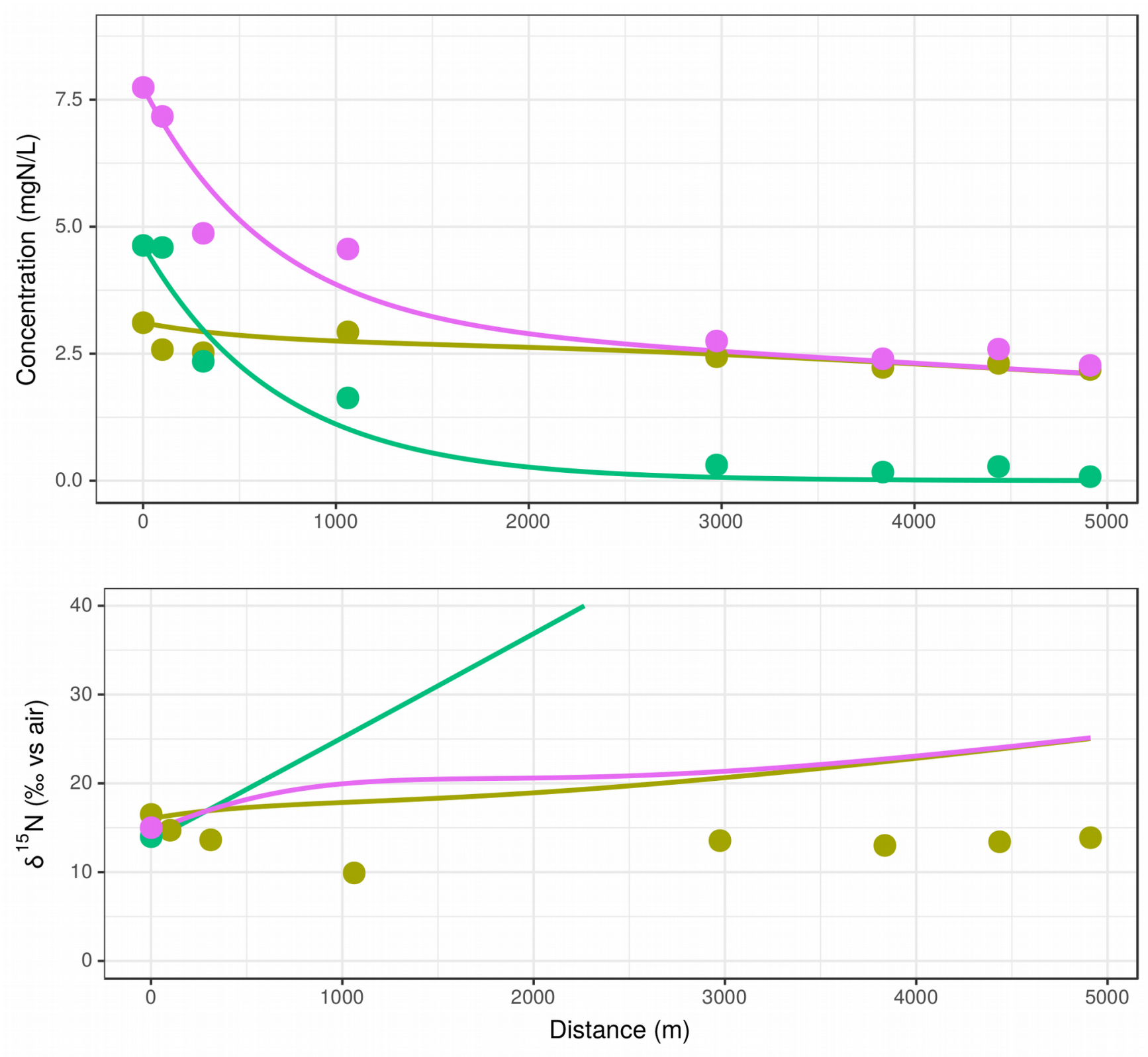

380 4. Waterloo wastewater treatment plants plumes on 2008-07-01. Measured field data are shown as 381 points. Best-fit model results are shown as curves. Parameters used in the model are given in Table. 382 Dissolved inorganic nitrogen (DIN $=\mathrm{TAN}+\mathrm{NO}_{3}{ }^{-}$and mass-weighted $\delta^{15} \mathrm{~N}$-DIN) is plotted to show 383 where there is nitrogen loss from the system either through degassing, assimilation or denitrification. 

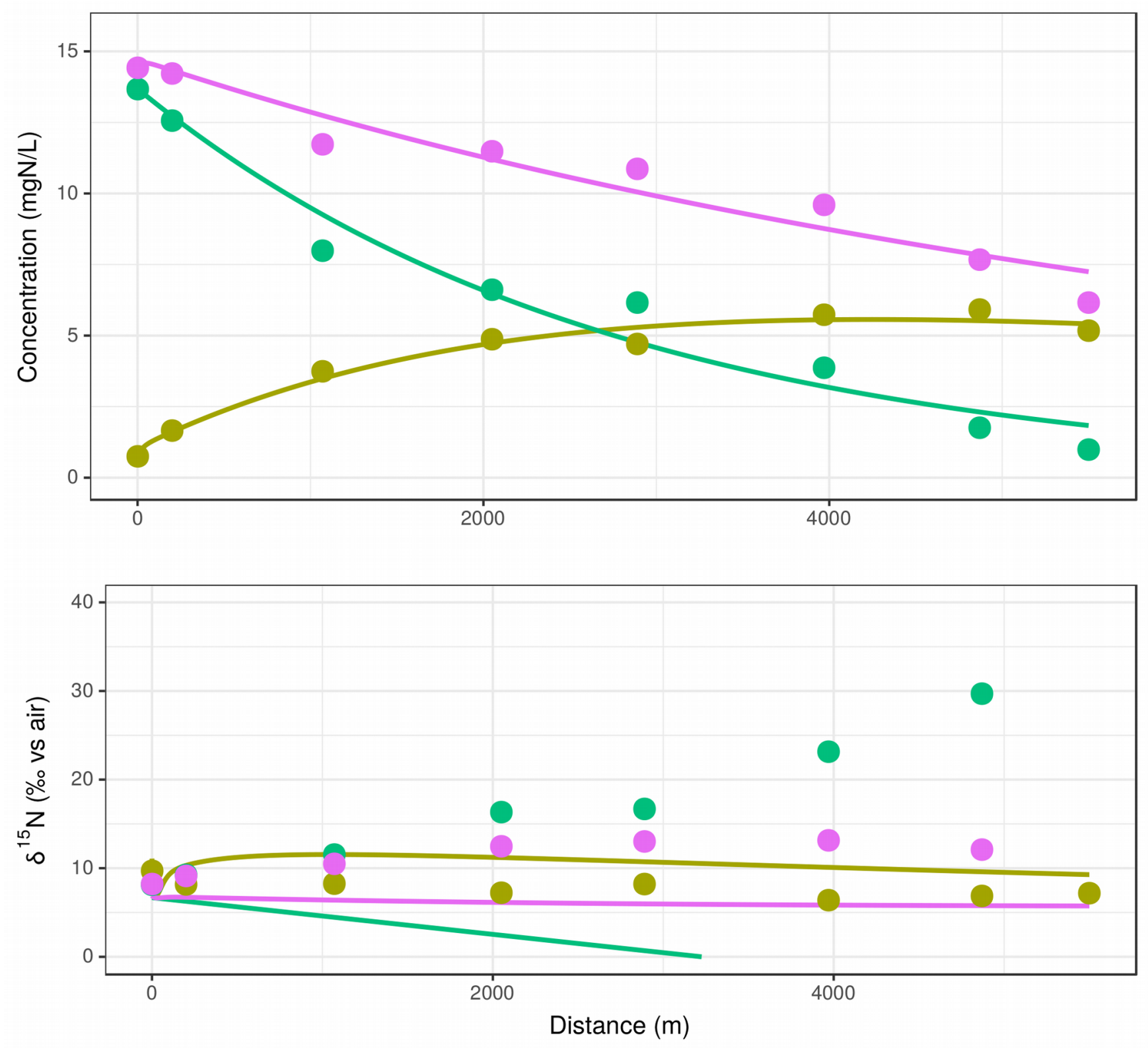

384 5. Kitchener wastewater treatment plants plumes in 2007-10-23. Measured field data are shown as 385 points. Best-fit model results are shown as curves. Parameters used in the model are given in Table.

386 Dissolved inorganic nitrogen (DIN $=\mathrm{TAN}+\mathrm{NO}_{3}{ }^{-}$and mass-weighted $\delta^{15} \mathrm{~N}-\mathrm{DIN}$ ) is plotted to show

387 where there is nitrogen loss from the system either through degassing, assimilation or denitrification. 

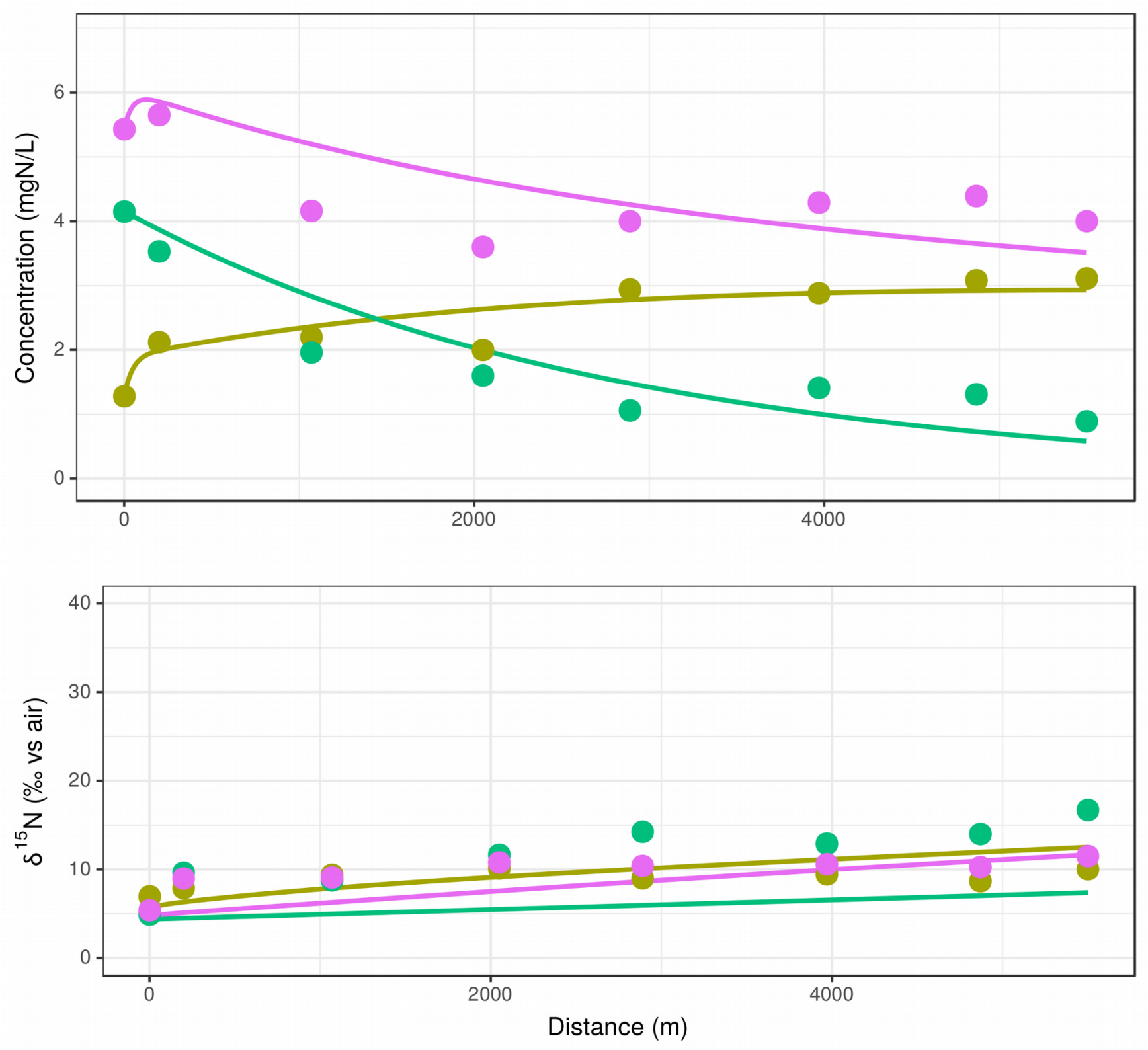

388 6. Kitchener wastewater treatment plants plumes in 2008-07-18. Measured field data are shown as 389 points. Best-fit model results are shown as curves. Parameters used in the model are given in Table.

390 Dissolved inorganic nitrogen (DIN $=\mathrm{TAN}+\mathrm{NO}_{3}{ }^{-}$and mass-weighted $\delta^{15} \mathrm{~N}-\mathrm{DIN}$ ) is plotted to show

391 where there is nitrogen loss from the system either through degassing, assimilation or denitrification. 


\section{Tables:}

393 Table 1. Parameters and typical values used in modelling wastewater treatment plant plumes in the Grand River, Ontario via

394 NANNO.

\begin{tabular}{|c|c|c|c|c|}
\hline Parameter & Description & $\begin{array}{l}\text { Typical value or } \\
\text { range }\end{array}$ & Units & Reference \\
\hline $\mathrm{k}_{\mathrm{ge}}$ & gas exchange coefficient & $0.0001-0.001$ & $\mathrm{t}^{-1}, \mathrm{~m}^{-1}$ & $\begin{array}{l}\text { (Jamieson et al } \\
2013, \\
\text { Venkiteswaran et } \\
\text { al 2015) }\end{array}$ \\
\hline $\mathrm{k}_{\text {nit } 1}$ & $\begin{array}{l}\text { nitrification rate constant: } \mathrm{NH}_{4}^{+} \text {to } \\
\mathrm{NO}_{2}^{-}\end{array}$ & $0-0.01$ & $\mathrm{t}^{-1}, \mathrm{~m}^{-1}$ & \\
\hline $\mathrm{k}_{\mathrm{nit} 2}$ & $\begin{array}{l}\text { nitrification rate constant: } \mathrm{NO}_{2}^{-} \text {to } \\
\mathrm{NO}_{3}^{-}\end{array}$ & $0-0.01$ & $\mathrm{t}^{-1}, \mathrm{~m}^{-1}$ & \\
\hline $\mathrm{k}_{\text {denit }}$ & denitrification rate constant & $0-0.001$ & $\mathrm{t}^{-1}, \mathrm{~m}^{-1}$ & \\
\hline $\mathrm{k}_{\mathrm{amup}}$ & ammonium uptake rate constant & $0-0.01$ & $\mathrm{t}^{-1}, \mathrm{~m}^{-1}$ & \\
\hline$\alpha_{\mathrm{NH} 3 \mathrm{NH} 4}$ & $\begin{array}{l}\text { equilibrium isotope fractionation } \\
\text { factor between } \mathrm{NH}_{3} \text { and } \mathrm{NH}_{4}^{+}\end{array}$ & 1.047 & unitless & $\begin{array}{l}\text { (Li et al 2012, } \\
\text { Hermes et al 1985) }\end{array}$ \\
\hline
\end{tabular}

$\alpha_{\mathrm{ge}} \quad$ kinetic isotope fractionation factor for $0.995-1.000 \quad$ unitless gas exchange of $\mathrm{NH}_{3}$

(Kirshenbaum et al 1947, Thode et al 1945, Norlin et al 2002)

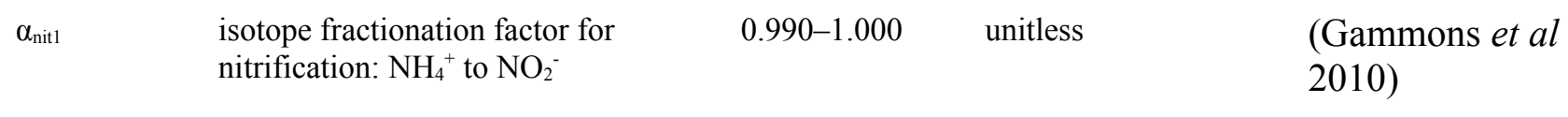

$\begin{array}{llccc}\alpha_{\text {nit2 }} & \begin{array}{l}\text { isotope fractionation factor for } \\ \text { nitrification: } \mathrm{NO}_{2}^{-} \text {to } \mathrm{NO}_{3}^{-}\end{array} & 0.990-1.000 & \text { unitless } & \begin{array}{l}\text { (Gammons } \text { et al } \\ \text { 2010) }\end{array} \\ \alpha_{\text {denit }} & \begin{array}{l}\text { isotope fractionation factor for } \\ \text { denitrification: } \mathrm{NO}_{3}^{-} \text {to } \mathrm{N}_{2} \mathrm{O}\end{array} & 0.985-1.000 & \text { unitless } & \text { (Sebilo et al 2003) } \\ \alpha_{\text {amup }} & & & \text { unitless } & \text { (Delwiche and } \\ & \text { isotope fractionation for } \mathrm{NH}_{4}^{+} \text {uptake } & 0.973-1.000 & & \text { Steyn 1970, }\end{array}$


Mariotti et al 1981,

Fogel and

Cifuentes 1993,

Hoch et al 1992)

$\begin{array}{lllll}\mathrm{pH} & \mathrm{pH} & 7.5-8.5 & \text { unitless } & \text { Measured in situ } \\ \text { Temp } & \text { temperature } & 10-20 & { }^{\circ} \mathrm{C} & \text { Measured in situ } \\ \mathrm{p} K_{\mathrm{a}} & \text { acid dissociation constant for } \mathrm{NH}_{4}{ }^{+} & 9.4 & \text { unitless } & \text { Calculate(Olofsson } \\ & & & & 1975)\end{array}$

395

396 
397

398

399

\section{0}

Table 2. Summary of all rates from best-fits. Reported as $\mathrm{X} \mathrm{mgN} / \mathrm{L}$ or mass of $\mathrm{N}$ transformed by each process in the river reaches under study..

\begin{tabular}{lllll}
\hline & Waterloo WWTP & Waterloo WWTP & Kitchener WWTP & $\begin{array}{l}\text { Kitchener WWTP } \\
\text { 2007-10-23 }\end{array}$ \\
& $2007-10-30$ & $2008-07-01$ & 0.18 \\
\hline $\mathrm{NH}_{3}$ Volatilization & 2.3 & 0.11 & 0.02 & 0.12 \\
$\mathrm{NH}_{4}{ }^{+}$Uptake & 0.16 & 0.37 & 5.0 & 1.9 \\
Nitrification & 2.1 & 7.3 & 8.4 & 3.0 \\
Denitrification & 3.0 & 4.1 & 0.30 & 0.41 \\
\hline
\end{tabular}

